\title{
Health Technology Assessment of Carbon-ion Beam Radiotherapy: A Systematic Review of Clinical Effectiveness and Safety for 54 Oncological Indications in 12 Tumour Regions
}

\author{
GREGOR GOETZ ${ }^{1}$, MARIJA MITIC ${ }^{2}$, TARQUIN MITTERMAYR ${ }^{1}$ and CLAUDIA WILD ${ }^{1}$ \\ ${ }^{1}$ Ludwig Boltzmann Institute for Health Technology Assessment (LBI-HTA), Vienna, Austria; \\ ${ }^{2}$ Ludwig Boltzmann Society, D.O.T. Research Group for Mental Health of Children and \\ Adolescents at Karl Landsteiner University of Health Sciences, Krems, Austria
}

\begin{abstract}
Background/Aim: Due to the unique physical dose distribution of carbon-ion radiotherapy (CIRT), CIRT can be regarded as a novel tumour irradiation technique - potentially advantageous for various tumour types. Yet it is unclear in how far, superiority or inferiority can be claimed when comparing CIRT to standard irradiation. This study aimed to assess the scientific evidence regarding the effectiveness and safety of CIRT. Materials and Methods: A systematic literature review was performed using the European Network for Health Technology Assessment (EUnetHTA) Core Model ${ }^{\circledR}$ for rapid relative effectiveness assessment. The literature search for clinical outcome studies on CIRT was performed using four databases [Cochrane (Central), Centre for Research and Dissemination (CRD), Embase and OVID MEDLINE]. The Cochrane Risk of Bias Tool (for randomised controlled trials) and the Institute of Health Economics (IHE-18) Checklist (for observational studies) were used to assess the risk of bias of the included studies. The evidence synthesis was restricted to 54 oncological indications in 12 broad tumour regions and studies with a low or moderate risk of bias, published between 2005 and 2017. Results: Twenty-seven studies were eligible for the qualitative synthesis of the evidence regarding the effectiveness and safety of CIRT: One randomised controlled trial that primarily focused on the feasibility of CIRT, three case-control
\end{abstract}

This article is freely accessible online.

Correspondence to: Gregor Goetz, MSSc MPH, Ludwig Boltzmann Institute for Health Technology Assessment, Garnisongasse 7/20, 1090 Vienna, Austria. Tel: +43 1236811924, e-mail: Gregor.Goetz@ hta.lbg.ac.at

Key Words: Carbon-ion radiotherapy, carbon-ion beam radiotherapy, local tumour therapy, local tumour therapy, diverse oncological indications, review. studies, three before- and after-studies with a focus on quality of life, and 20 further studies of case series. Overall, insufficient scientific evidence was found for superiority or inferiority of CIRT when compared to standard irradiation for 13/54 oncologicaI indications in 7/12 tumour regions (skull base tumours, brain cancer, cancer in the ear-nose-throat region, bone and soft-tissue tumours, lung cancer, prostate cancer, gastrointestinal tumours). No scientific evidence was found for the remaining 41/54 oncological indications. Conclusion: CIRT is undoubtedly, theoretically, a promising cancer treatment. To date, however, it lacks randomised controlled trials assessing the long-term effectiveness and harms associated with the use of CIRT. CIRT must be considered as an experimental treatment due to the lack of high-quality clinical research.

Carbon-ion radiotherapy (CIRT) is a novel therapy for treating cancer. CIRT has raised the expectation of achieving higher local control while lowering the probability of damaging surrounding healthy tissues. This is realised by the focused physical distribution of the radiation beams and a high linear energy transfer associated with CIRT (1). CIRT is, however, often described as a two-edged sword (2), highlighting the need to differentiate its application for different oncological indications. That is to say, CIRT may also affect healthy tissues and increase the risk of severe injury to critical organs.

Within the past decades, internationally, numerous cancer therapy centres offering CIRT have been established (3). Currently, CIRT is offered at 11 cancer therapy centres worldwide, with the majority of these being located in Asia (with five and two centres in Japan and China, respectively) and a few in Europe (with two, one, and one centre located in Germany, Italy and Austria, respectively) (3). A further five facilities located in Asia, offering CIRT in the future, are in the construction or planning phase (3). Overall, 21,580 patients were documented as having been treated with CIRT until the end of 2016 (4). 
As a result of the increasing provision of CIRT, many decision makers in health care are confronted with the question whether CIRT should be reimbursed according to scientific evidence showing patient-relevant benefits and, if so, for which indications. For reimbursement decisions, it is mandatory in many countries to evaluate whether the promising theoretical advantages of CIRT are translated into clinical benefits, that is, longer survival and reduced sideeffects.

Since MedAustron, the Austrian hadron-therapy centre, started to provide proton radiotherapy (PRT) in 2018 and will start with CIRT in 2019, the Ludwig Boltzmann Institute for Health Technology Assessment (LBI-HTA) was asked to conduct a systematic review on the effectiveness and safety of CIRT as decision support (5). This article describes the results of the review conducted by the LBI-HTA, answering the question of whether CIRT is more or equally effective/safe than conventional radiotherapy. The aim was, hereby, to provide an overview of the evidence regarding the effectiveness (i.e. mortality, morbidity, and quality of life) and safety of CIRT for 54 oncological indications in 12 tumour regions.

\section{Materials and Methods}

A systematic literature review was conducted using the EUnetHTA Core Mode ${ }^{\circledR}$ for rapid relative effectiveness assessment as reporting format (6). The study was also undertaken in accordance with the PRISMA statement (7).

Search strategy. A systematic literature search for identifying clinical studies on CIRT, written in English, German, or French, was carried out between the 5th and 7th of September, 2017, using Cochrane (Central), Centre for Research and Dissemination (CRD), Embase and OVID MEDLINE [the search strategies can be found in the Appendix of the original report (5); available online]. A hand-search in clinical trial registries (e.g. clinicaltrials.gov), on websites of cancer therapy centres offering CIRT, and the Particle Therapy CoOperative Group (PTCOG), supplemented the systematic search.

Selection criteria, study selection, selected outcomes, and data extraction. Studies that enrolled patients with any of the specified pre-defined 12 tumour regions and 54 specific oncological indications (as shown in Table I) receiving CIRT were eligible to be included in this assessment. Conventional (photon) radiotherapy was the preferred control intervention, but no filter was set. Furthermore, only randomised controlled trials (RCTs), controlled trials, and prospective observational studies were eligible for inclusion. The following eligibility criteria applied additionally for the evidence synthesis:

Overlapping sample: Older publications with the same patient sample were excluded. When it was not clear whether it was the same sample, or if other crucial outcomes were reported, the studies were included.

Sample size: Only studies with more than 10 patients were eligible.

Low/moderate risk of bias (RoB): For uncontrolled studies, only studies with low or moderate RoB were eligible for inclusion for the qualitative evidence synthesis. The quality appraisal was conducted using the Institute of Health Economics (IHE-18) checklist (8). Further description of the pre-defined cut-off used can be found in the original report (5); available online.

Publication period: Only those studies published between 2005 and 2017 were included.

When a study reported on a sample with patients with different indications, it was considered as evidence if more than 10 patients and at least $40 \%$ of the total sample suffered from the specific oncological indication.

Due to the scarcity of high-level evidence studies, no further filters were used, e.g. regarding the length of follow-up. An overview of all inclusion and exclusion criteria according to the PICOS question can be found in Table I.

For the study selection, two independent researchers (GG, MM) screened the abstracts and reviewed the articles that were eligible for the full-text screening, guided by the pre-defined inclusion criteria. Discrepancies were solved by consensus, and a third researcher (CW) was consulted when conflicts could not be resolved.

For the evaluation of the comparative effectiveness of CIRT, mortality and mortality-related outcomes, as well as other patientrelevant outcomes, were selected. That is, the following endpoints were judged to be crucial: Overall survival (OS), cause-specific survival (CSS)/disease-specific survival (DSS), recurrence-free survival (RFS), progression-free survival (PFS), disease-free survival (DFS), change in health-related quality of life (HRQoL). For the evaluation of the comparative safety of CIRT, acute and late radiation morbidities were selected.

The data of the eligible studies were extracted by means of piloted LBI-HTA forms for systematic reviews. Data were extracted by one researcher (GG) and controlled by another researcher (MM). All evidence tables can be found in the original report (5), available online.

Quality appraisal. The internal validity of the identified studies was assessed by two independent researchers (GG, MM), applying the EUnetHTA guidelines $(9,10)$. For the included feasibility study that defined itself as a randomised phase II study (11), the Cochrane RoB tool (12) was applied. For the remaining uncontrolled observational studies, the RoB was assessed using the IHE-18 checklist (8). The RoB was classified into three categories: Low (score: 14.5-18), moderate (score: 11-14), and high (score $\leq 10.5$ ). More information on the documented quality appraisal, point system used and the cutoff level used to assess the RoB can be found in the original report (5), available online.

Analysis. For the evidence synthesis, no inferential statistical analysis was performed due to the lack of RCTs and non-randomised controlled studies. A qualitative analysis and synthesis of the evidence was conducted.

\section{Results}

Search results. The database search and the hand search resulted in 414 records after de-duplication. The abstract screening process revealed that 265 studies did not meet the inclusion criteria. As a result, 149 full-text articles were assessed for eligibility. A total of 122 records were not eligible and excluded with reason, resulting in 27 studies 
Table I. Inclusion and exclusion criteria according to the PICOS question based on the conducted health technology assessment (5).

\begin{tabular}{|c|c|c|}
\hline & Inclusion criteria & Exclusion criteria \\
\hline Population & $\begin{array}{l}\text { Patients with any of the } 54 \text { oncological indications in } 12 \text { tumour regions: } \\
\text { - Skull base (13 indications): Chordoma, chondrosarcoma, meningioma grade II/grade III, } \\
\text { meningioma grade I (complex), craniopharyngioma, pituitary adenoma (not suitable for } \\
\text { stereotaxis), acoustic neuroma, other neurinomas, glomus tumour, retinoblastoma, lachrymal } \\
\text { gland tumours, sarcomas incl. Ewing's sarcoma, rhabdomyosarcomas of the skull base and orbit } \\
\text { - Eye (1 indication): Choroid melanoma } \\
\text { - Brain (6 indications): Glioma grade II, glioma grade III, glioblastoma, ependymoma, } \\
\text { medulloblastoma, other childhood brain tumours } \\
\text { - ENT ( } 11 \text { indications): Orbital tumours, tumour of the nasal cavity and paranasal sinus, } \\
\text { maxillary sinus carcinoma, nasopharyngeal carcinoma, oropharyngeal carcinoma, tonsil } \\
\text { carcinoma, tongue base carcinoma, salivary gland carcinoma (pleomorphic), salivary gland } \\
\text { carcinoma (adenoid cystic), sarcoma in the ENT area including Ewing's sarcoma, rhabdomyosarcoma } \\
\text {-Lung ( } 3 \text { indications): Non-small cell lung carcinomas, mediastinal tumours (including thymoma), } \\
\text { pleural mesothelioma } \\
\text { - Gastrointestinal (6 indications): Esophageal carcinoma, pancreatic cancer, liver carcinoma, } \\
\text { rectal carcinoma recurrence presacral, schwannomas/malignant schwannomas, Ewing's sarcoma } \\
\text { - Bone and soft tissue (5 indications): Osteosarcoma, soft-tissue sarcoma, spinal/sacral chordoma, } \\
\text { spinal/sacral chondrosarcoma, spinal meningioma } \\
\text { - Prostate ( } 1 \text { indication): Prostate cancer } \\
\text { - Breast ( } 1 \text { indication): Breast cancer } \\
\text { - Kidney ( } 1 \text { indication): Nephroblastoma } \\
\text { - Nervous system ( } 1 \text { indication): Neuroblastoma } \\
\text { - Haematological cancer ( } 2 \text { indications): Non-Hodgkin's lymphoma, } \\
\text { Hodgkin's lymphoma } \\
\text { Other ( } 3 \text { indications): Solitary liver metastases in colorectal cancer, Retroperitoneal } \\
\text { metastases in controlled primary tumours, oligometastasis in controlled primary tumours } \\
\text { in selected indications }\end{array}$ & $\begin{array}{l}\text { All other pathological } \\
\text { conditions that are not } \\
\text { listed under the } \\
\text { inclusion criteria. }\end{array}$ \\
\hline Intervention & Carbon-ion radiotherapy & $\begin{array}{l}\text { Other forms of } \\
\text { radiotherapy, surgery }\end{array}$ \\
\hline $\begin{array}{l}\text { Control } \\
\text { Outcomes }\end{array}$ & Photon radiation therapy; secondary: Proton radiotherapy, all other forms of radiotherapy, surgery & No restriction \\
\hline Efficacy & $\begin{array}{l}\text { Overall survival, cause-specific survival/disease-specific survival, disease-free survival, } \\
\text { recurrence-free survival, progression-free survival, local control rate, health-related quality of life }\end{array}$ & All other outcomes \\
\hline Safety & Toxicity: Acute and late radiation morbidity & All other outcomes \\
\hline Study design & $\begin{array}{l}\text { Randomised controlled trials } \\
\text { Non-randomised controlled trials, prospective case series with more than } 10 \text { patients }\end{array}$ & $\begin{array}{l}\text { Retrospective case series, } \\
\text { case reports, commentaries, } \\
\text { prospective case series } \\
\text { with } 10 \text { or fewer patients; } \\
\text { studies only published as } \\
\text { an abstract. }\end{array}$ \\
\hline $\begin{array}{l}\text { Language } \\
\text { Publication period }\end{array}$ & $\begin{array}{l}\text { German/English/French } \\
\text { 2005-2017 }\end{array}$ & All other languages \\
\hline
\end{tabular}

ENT: Ear-nose-throat.

eligible for data extraction and qualitative synthesis of the evidence of CIRT (see Figure 1).

Literature review. In total, 27 studies were judged as being eligible for the qualitative synthesis of the effectiveness and safety of CIRT when compared to standard irradiation: one RCT was included that focused on the toxicity/feasibility of CIRT/PRT in patients with prostate cancer. This RCT was judged to have a high RoB. The remaining 26 included studies were either case series $(n=20)$, or, less frequently, case-control studies $(n=3)$ or single-arm before-after studies $(n=3)$.

Overall, due to the lack of comparative clinical trials, there was insufficient evidence for the superiority/inferiority of the effectiveness of CIRT for 13 out of 54 indications in seven out of 12 tumour regions (5), namely: skull base (chordoma and chondrosarcoma), brain (glioma grade II, glioma grade III, glioblastoma), ear-nose-throat (ENT; sarcomas in the head and neck, tumours in the nasal cavity and paranasal sinus, 

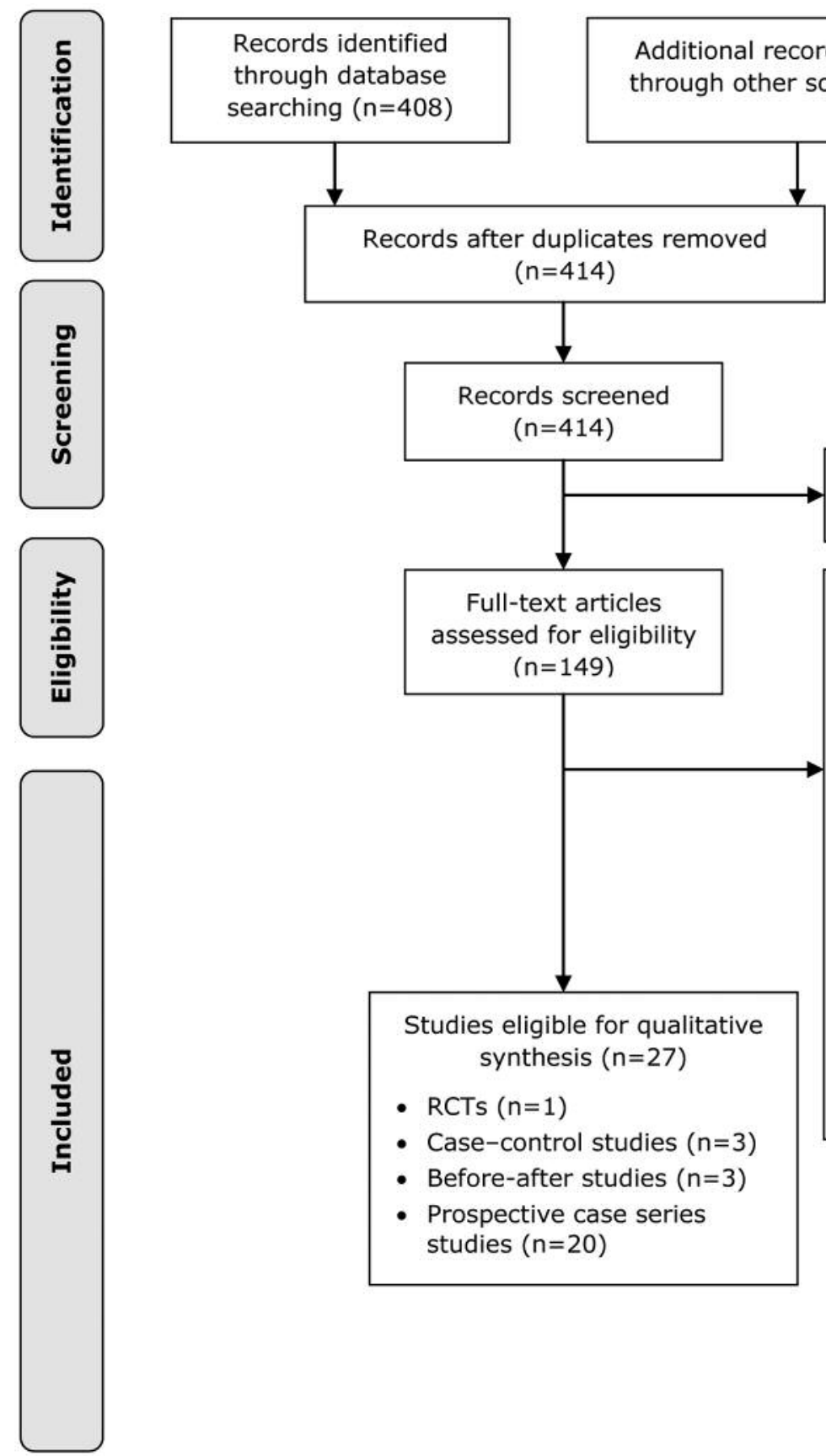

Records excluded $(n=265)$

- Full-text articles excluded, with reason $(n=122)$

- Abstract only $(n=31)$

- Wrong language $(n=16)$

- Protocol $(n=15)$

- Wrong study design $(n=14)$

- HTA reports/Systematic reviews on charged particles $(n=9)$

- Double publication $(n=3)$

- Commentary $(n=2)$

- Wrong intervention $(n=2)$

- $\leq 10$ Patients $(n=1)$

- High risk of bias $(n=19)$

- Before $2005(n=2)$

- Wrong indication $(n=8)$

Figure 1. Flowchart of study selection (PRISMA flow diagram) based on the conducted health technology assessment (5).

adenoid cystic salivary gland carcinoma), bone and soft tissue (soft-tissue sarcoma), lung (non-small cell lung carcinoma), prostate (prostate carcinoma), and, gastrointestinal tumours (oesophageal carcinoma, rectal carcinoma).

For tumours in the skull base region (see Table II), three case series studies were included (13-15): None of the studies compared CIRT to conventional radiotherapy. Therefore, insufficient scientific evidence was found indicating superiority/inferiority of CIRT in comparison to standard irradiation for chordomas and low-grade chondrosarcoma. For brain tumours (see Table II), two case series studies represented the evidence base $(16,17)$ : None of the studies compared CIRT to conventional radiotherapy. Thus, insufficient scientific evidence was found indicating superiority/inferiority of CIRT 
in comparison to standard irradiation for WHO grade II gliomas, WHO grade III gliomas, and glioblastomas (WHO grade IV gliomas).

The evidence base for the use of CIRT for ENT tumours was five studies (see Table II): Four case series (18-21) and one case-control study (22). None of the studies was controlled, comparing CIRT to standard irradiation. Therefore, we found insufficient scientific evidence indicating superiority/inferiority of CIRT in comparison to standard irradiation for sarcomas in the head and neck, tumours in the nasal cavity and paranasal sinus, and adenoid cystic salivary gland carcinomas. The case-control study indirectly (historical control) compared CIRT in combination with photon therapy $(n=29)$ to photon therapy alone $(n=34)$ in patients with locally advanced adenoid cystic carcinoma of the salivary gland. The statistical analysis of the study revealed no statistically significant difference when comparing OS between groups (22).

For tumours in the lung region, six clinical studies (23-28) were included (see Table III). Due to the absence of a controlled study, insufficient scientific evidence was found indicating superiority/inferiority of CIRT in comparison to standard irradiation for non-small cell lung carcinomas (NSCLC). Indirect comparisons between CIRT and PRT were conducted in two studies and showed no statistically significant difference on the basis of OS $(25,26)$, when comparing patients treated with CIRT to those treated with PRT (indication: IB/IIA patients with NSCLC) $(25,26)$.

For bone and soft-tissue sarcomas (see Table III), one case series study that enrolled patients with primary sarcomas of the extremities met the inclusion criteria (29) (see Table III). None of the studies compared CIRT to other cancer treatments. Therefore, insufficient scientific evidence was found indicating superiority/inferiority of CIRT in comparison to standard irradiation for bone and soft-tissue sarcoma.

For gastrointestinal tumours (see Table IV), two studies met the inclusion criteria $(30,31)$ (see Table IV). Due to the absence of a controlled study, insufficient scientific evidence was found indicating superiority or inferiority of CIRT in comparison to standard irradiation for thoracic oesophageal squamous cell carcinoma and rectal cancer without distant metastases (evidence base: one prospective case series respectively).

For prostate cancer, eight studies met the inclusion criteria (see Table IV): One study was an RCT parallel assigned, pilot study that focused primarily on the toxicity of CIRT in comparison to PRT (11); three studies were before-after studies measuring primarily health-related quality of life of the patients (32-34); and four further studies were case series. Of the latter, one study was an interim report of acute sideeffects (35); one was a dose-escalation study (36); one was a multi-institutional case series study (37); and one further study was a phase II case series study focusing on the efficacy and feasibility of CIRT (38). The RCT had a high RoB and found no direct statistically significantly different toxicity profile when comparing both experimental arms; PRT $(n=46)$ and CIRT $(n=45)(11)$. The same study stated that comparable quality of life was prevalent when comparing CIRT to PRT at 6 months of follow-up (11). No other comparisons were conducted by the other studies. Thus, insufficient scientific evidence was found indicating superiority or inferiority of CIRT in comparison to standard irradiation for prostate cancer.

For the remaining 41 oncological indications, no scientific evidence was found indicating superiority/inferiority of CIRT when compared to conventional radiotherapy based on our pre-defined inclusion criteria.

\section{Discussion}

The systematic review revealed that there is insufficient scientific evidence showing superiority or inferiority of CIRT when compared to conventional radiotherapy for $13 / 54$ indications in $7 / 12$ tumour regions. No scientific evidence was found for the remaining 41 oncological indications. Therefore, neither superiority nor inferiority can be claimed from the current best available evidence of CIRT when compared to standard irradiation.

The results of this systematic review on CIRT are aligned with those of other published scientific (systematic) reviews. In 2018, one review summarised potential indications for CIRT and reviewed both biophysical properties and current clinical evidence available (39). The review was conducted at the same time as the report of the LBI-HTA (5) with similar results, and highlighted the need for randomised phase III studies comparing CIRT to other radiation modalities.

In addition, one recent systematic review on charged particle therapy for hepatocellular carcinoma (40), identified four CIRT studies, without comparison of CIRT to standard irradiation. Another systematic review conducted in 2013 found no RCT and concluded that CIRT should be considered as an experimental treatment, and comparisons (using RCTs) of CIRT and photon as well as PRT are necessary (41).

Furthermore, another systematic review conducted both a qualitative and quantitative evidence synthesis using 86 observational studies. The review identified five CIRT studies and did find statistically significantly higher 5-year survival when comparing CIRT to photon radiotherapy in patients with mucosal malignant melanoma (44\% vs. $25 \%, p=0.007)$ (42). While those results do indeed sound promising and may, at first sight, indicate CIRT may be superior for this oncological indication, significant limitations must be mentioned. The evidence base of the meta-analysis were observational studies leading to an increased RoB by default, and it is questionable if heterogeneity was adequately analysed. That is, the percentage of patients having undergone operation was not 
Table II. Summary results of the evidence of efficacy and safety of carbon-ion radiotherapy (CIRT) for tumours in the skull base and brain and earnose-throat (ENT) region.

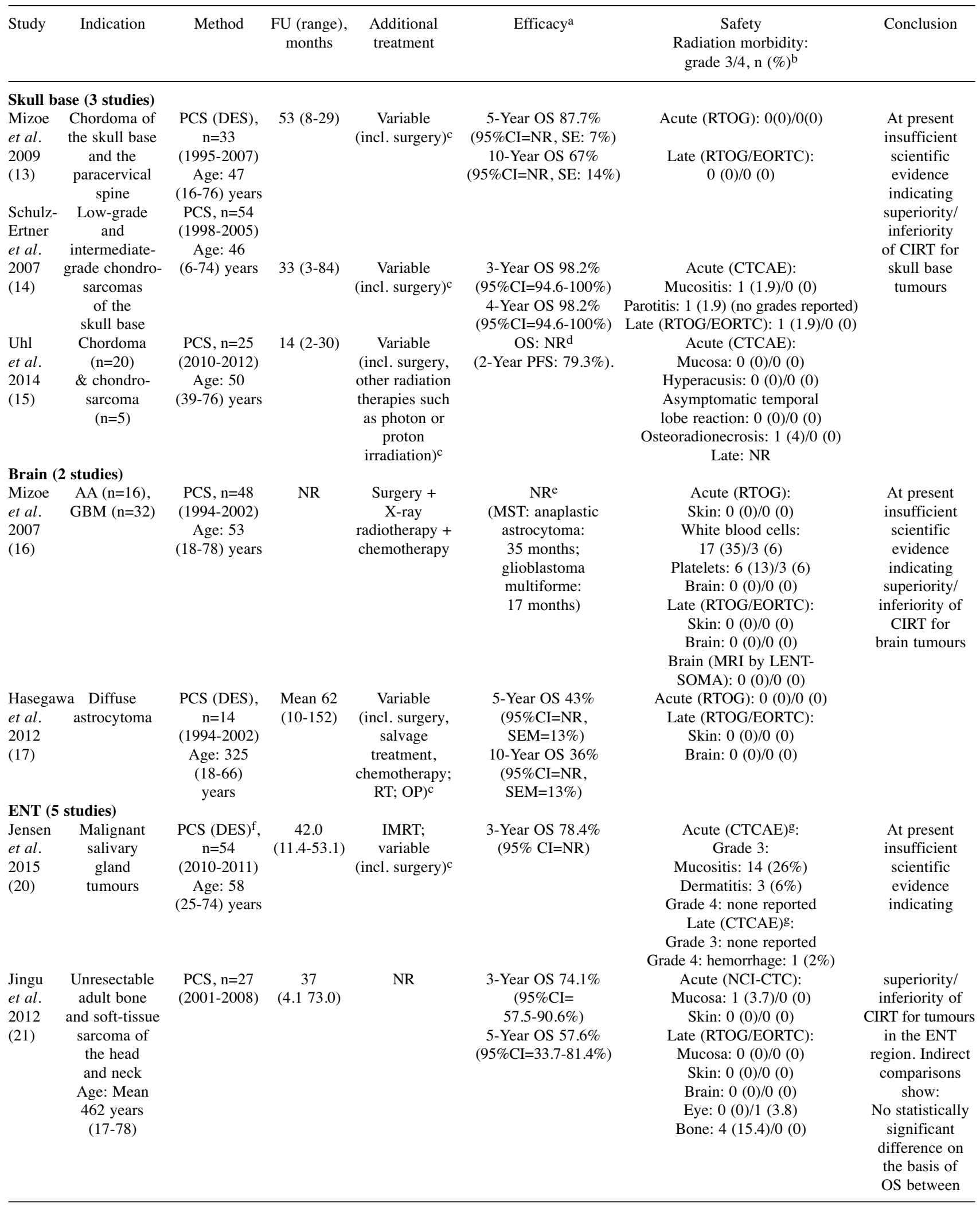


Table II. Continued

\begin{tabular}{|c|c|c|c|c|c|c|c|}
\hline Study & Indication & Method & $\begin{array}{l}\text { FU (range), } \\
\text { months }\end{array}$ & $\begin{array}{c}\text { Additional } \\
\text { treatment }\end{array}$ & Efficacya & $\begin{array}{l}\text { Safety } \\
\text { Radiation morbidity: } \\
\text { grade } 3 / 4, \mathrm{n}(\%)^{\mathrm{b}}\end{array}$ & Conclusion \\
\hline
\end{tabular}

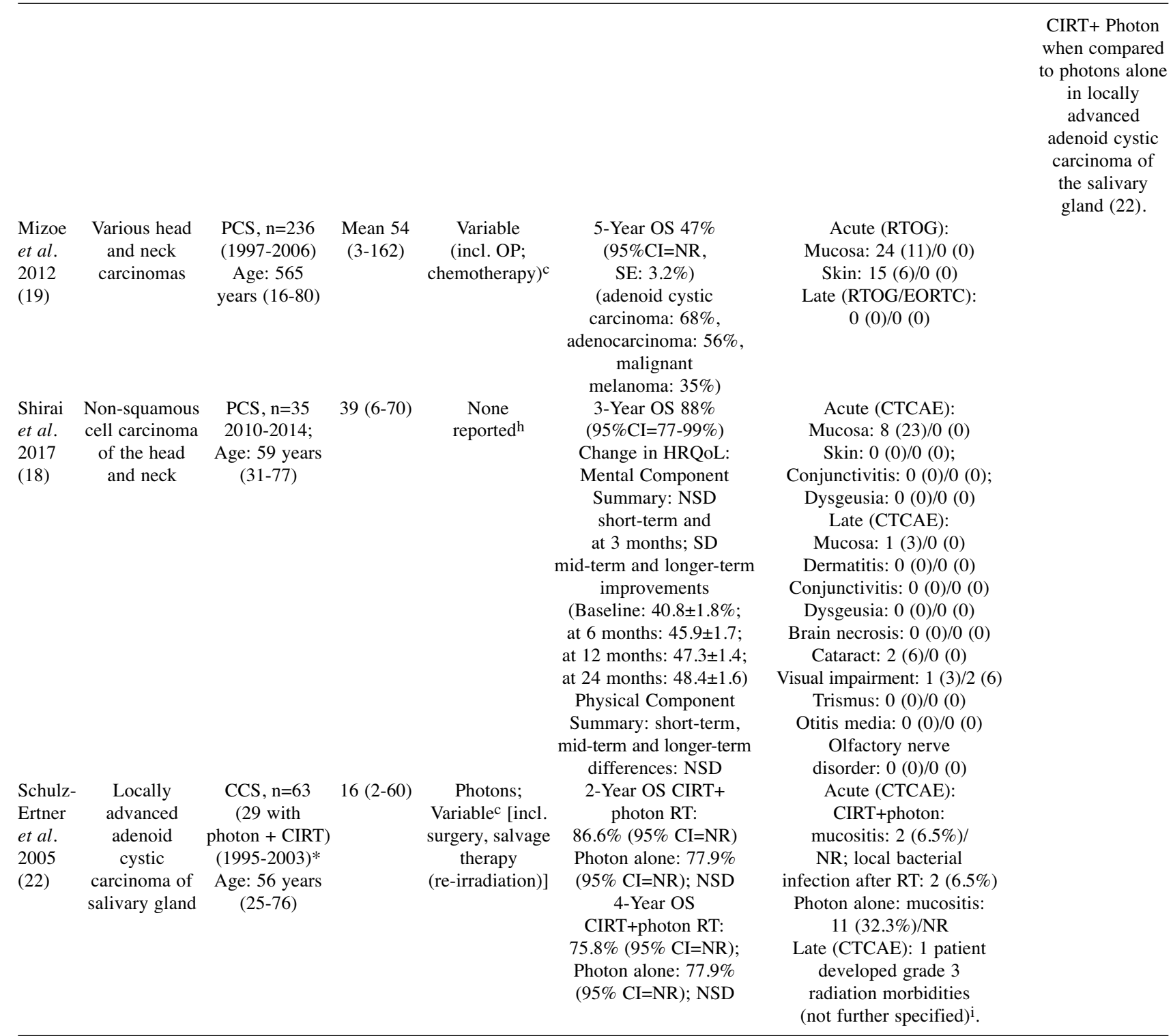

AA: Anaplastic astrocytoma; CCS: case-control study; CI: confidence interval; CIRT: carbon-ion radiotherapy; CTCAE: Common Terminology Criteria for Adverse Events; DES: dose-escalation study; ENT: ear-nose-throat; EORTC: European Organisation for Research and Treatment of Cancer; FU: follow-up; GBM: glioblastoma multiforme; HRQoL: health-related quality of life; IMRT: intensity-modulated radiation therapy; incl.: including; LENT-SOMA: Late Effects Normal Tissue Task Force Subjective, Objective Management Analytic; MST: median survival time; MRI: magnetic resonance; n. s.: not statistically significant; NCI-CTC: National Cancer Institute-Common Toxicity Criteria; NR: not reported; NSD: not statistically significantly different; OP: operation; OS: overall survival; PCS: prospective case series; PRT: proton radiotherapy; RT: radiotherapy; RCT: randomised controlled trial; RTOG: Radiation Therapy Oncology Group; SD: significantly different; SE: standard error; SEM: standard error of the mean. *Control group of 34 patents receiving photon RT. Notes: Data are based on the original health technology assessment (5). Age and FU in months are median

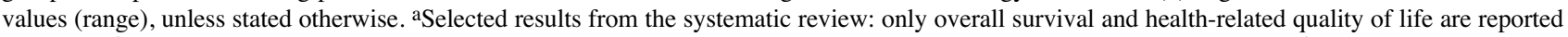

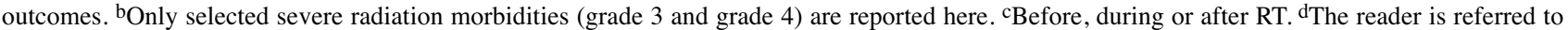
the primary study (14) and (5). ${ }^{\text {e}}$ The reader is referred to the primary study (16) and (5). fPatients received CIRT as a carbon-ion boost. gNumerous other toxicities occurred without grades reported: The study did not report on the grades for numerous observed late radiation morbidities. The reader is referred to the primary study and Table A-4 in the Appendix of (5). hHistory of irradiation to the head and neck and of chemotherapy within 1 month before CIRT were, among others, exclusion criteria. No detailed description of prior treatment (e.g. history of chemotherapy) was reported. iUnclear which treatment group the patient belonged to. For further details, readers are referred to the original health technology assessment (5). 
Table III. Summary results of the evidence of efficacy and safety of carbon-ion radiotherapy (CIRT) for lung and bone and soft-tissue cancer.

\begin{tabular}{|c|c|c|c|c|c|c|c|}
\hline Study & Indication & Method & $\begin{array}{l}\text { FU (range) } \\
\text { months }\end{array}$ & $\begin{array}{c}\text { Additional } \\
\text { treatment }\end{array}$ & Efficacy ${ }^{a}$ & $\begin{array}{c}\text { Safety } \\
\text { Radiation morbidity: } \\
\text { grade } 3 / 4, \mathrm{n}(\%)^{\mathrm{b}}\end{array}$ & Conclusion \\
\hline \multicolumn{8}{|c|}{ Lung (6 studies) } \\
\hline $\begin{array}{l}\text { Iwata } \\
\text { et al. } \\
2010 \\
(26)\end{array}$ & $\begin{array}{l}\text { NSCLC: } \\
\text { stage IA } \\
(\mathrm{n}=42)+ \\
\text { IB }(n=38)\end{array}$ & $\begin{array}{c}\text { CCS, } \mathrm{n}=80 \\
\text { (CIRT: } 23) \\
(2003-2007)^{* 1} \\
\text { Age: } 75 \\
\text { (54-89) years. }\end{array}$ & 30.5 (4-66) & NR & $\begin{array}{c}\text { 3-Year OSc: } \\
\text { CIRT }(\mathrm{n}=23): \\
86 \%(95 \% \mathrm{CI}=\mathrm{NR}) \\
\text { PRT1 }(\mathrm{n}=20): \\
\text { 90\% }(95 \% \mathrm{CI}=\mathrm{NR}) \\
\text { PRT2 }(\mathrm{n}=37): \\
61 \%(95 \% \mathrm{CI}=\mathrm{NR}) \\
\text { NSD between } \\
\text { treatment protocols }\end{array}$ & $\begin{array}{c}\text { Acute: NR } \\
\text { Late (CTCAE): } \\
\text { CIRT }(\mathrm{n}=23) \text { : } \\
\text { Lung: } 0(0) / 0(0) \\
\text { Skin: } 0(0) / 0(0) \\
\text { PRT }(\mathrm{n}=57): \\
\text { Lung: } 1(1.8) / 0(0) \\
\text { Skin: } 3(5.3 \%) / 0(0)\end{array}$ & $\begin{array}{c}\text { At present, } \\
\text { insufficient } \\
\text { scientific } \\
\text { evidence } \\
\text { indicating } \\
\text { superiority/ } \\
\text { inferiority of } \\
\text { CIRT for } \\
\text { NSCLC when } \\
\text { compared to } \\
\text { conventional RT } \\
\text { Indirect } \\
\text { comparison: } \\
\text { NSD on the basis } \\
\text { of OS (25, 26) } \\
\text { between CIRT } \\
\text { when compared } \\
\text { to PRT for stage } \\
\text { IB/IIA NSCLC. }\end{array}$ \\
\hline
\end{tabular}

\begin{tabular}{|c|c|c|c|c|c|c|}
\hline $\begin{array}{l}\text { Iwata } \\
\text { et al. } \\
2013 \\
(25)\end{array}$ & $\begin{array}{l}\text { NSCLC: } \\
\text { stage IB } \\
(\mathrm{n}=47)+ \\
\text { IIA }(\mathrm{n}=23)\end{array}$ & $\begin{array}{c}\text { CCS, } \mathrm{n}=70 \\
(\mathrm{CIRT}: 27) \\
(2003-2009) * 2 \\
\text { Age: } 75 \\
\text { (57-92) years. }\end{array}$ & $44(4-103)$ & NR & $\begin{array}{l}\text { Outcomes only measured } \\
\text { for all patients } \\
\text { (CIRT and PRT) } \\
\text { 4-Year OS } 58 \% \\
(95 \% \text { CI }=46-70 \%) \\
\text { IIA: } 67 \%, \text { IB: } 53 \% \\
\text { NSD PRT and CIRT } \\
\text { (rates NR). }\end{array}$ & $\begin{array}{c}\text { Acute: NR } \\
\text { Late (CTCAE): } \\
\text { Lung: } 2(8.7) / 0(0) \\
\text { Skin: } 4(5.7) / 1(1.4)\end{array}$ \\
\hline $\begin{array}{l}\text { Miyamoto } \\
\text { et al. } \\
2007 \\
(28)\end{array}$ & $\begin{array}{l}\text { NSCLC: } \\
\text { stage IA } \\
(\mathrm{n}=42)+ \\
\text { IB }(\mathrm{n}=37)\end{array}$ & $\begin{array}{c}\text { PCS, } n=79 \\
(2000-2003) \\
\text { Age: Mean } \\
74.8(47-88) \\
\text { years. }\end{array}$ & $\begin{array}{c}38.6 \\
(2.5-72.2)\end{array}$ & NR & $\begin{array}{c}\text { 5-Year OS } 45 \% \\
(95 \% \mathrm{CI}=\mathrm{NR}) \\
\text { IA: } 62 \%, \mathrm{IB}: 25 \%\end{array}$ & $\begin{array}{c}\text { Acute (RTOG): } \\
\text { Lung: } 0(0) / 0(0) \\
\text { Skin: } 0(0) / 0(0) \\
\text { Late (RTOG/EORTC): } \\
\text { Lung: } 0(0) / 0(0) \\
\text { Skin: } 0(0) / 0(0)\end{array}$ \\
\hline $\begin{array}{l}\text { Miyamoto } \\
\text { et al. } \\
2007 \text { (27) }\end{array}$ & $\begin{array}{l}\text { NSCLC: } \\
\text { stage IA } \\
(\mathrm{n}=29)+\mathrm{I} \\
\mathrm{B}(\mathrm{n}=21)\end{array}$ & $\begin{array}{c}\text { PCS, } n=50 \\
(1999-2000) \\
\text { Age: Mean } \\
74.1(61-84) \\
\text { years. }\end{array}$ & $\begin{array}{c}59.2 \\
(6.0-83.0)\end{array}$ & NR & $\begin{array}{c}5 \text {-Year OS } 50 \% \\
(95 \% \mathrm{CI}=\mathrm{NR}) \\
\text { IA } 55.2 \%, \mathrm{IB}: 42.9 \%\end{array}$ & $\begin{array}{c}\text { Acute (RTOG): } \\
\text { Lung: } 0(0) / 0(0) \\
\text { Skin: } 0(0) / 0(0) \\
\text { Late (RTOG/EORTC): } \\
\text { Lung: } 0(0) / 0(0) \\
\text { Skin: } 1(1.9) / 0(0)\end{array}$ \\
\hline $\begin{array}{l}\text { Takahashi } \\
\text { et al. } \\
2015 \text { (24) }\end{array}$ & $\begin{array}{c}\text { Locally } \\
\text { advanced } \\
\text { NSCLC } \\
\text { stage IIA } \\
(\mathrm{n}=17)+ \\
\text { IIB }(\mathrm{n}=22) \\
\quad+ \\
\text { IIIA }(\mathrm{n}=23)\end{array}$ & $\begin{array}{c}\text { PCS (DES), } \\
n=62 \\
(2000-2013) \\
\text { Age: } 76 \\
\text { (46-88) years. }\end{array}$ & $\begin{array}{c}25.2 \\
(1.6-157.2)\end{array}$ & $\begin{array}{l}\text { Variable } \\
\text { (incl. } \\
\text { neoadjuvant } \\
\text { therapy, } \\
\text { salvage } \\
\text { chemotherapy) } \\
\text { ch }\end{array}$ & $\begin{array}{c}\text { 1-Year OS } 77.2 \% \\
(95 \% \text { CI }=66.7-87.7 \%) \\
2-\text { Year OS } 51.9 \% \\
(95 \% \text { CI }=39.2-64.5 \%)\end{array}$ & $\begin{array}{c}\text { Acute (CTCAE): } \\
\text { Lung: } 1(1.6) / 0(0) \\
\text { Skin: } 0(0) / 0(0) \\
\text { Late (RTOG/EORTC): } \\
\text { Lung: } 0(0) / 0(0) \\
\text { Skin: } 0(0) / 0(0) \\
\text { Oesophagus: } 1(1.6) / 0(0)\end{array}$ \\
\hline $\begin{array}{l}\text { Yamamoto } \\
\text { et al. } \\
2017 \\
(23)\end{array}$ & $\begin{array}{l}\text { NSCLC: } \\
\text { stage IA } \\
(\mathrm{n}=123)+ \\
\text { IB }(\mathrm{n}=95)\end{array}$ & $\begin{array}{c}\text { PCS }(\mathrm{DES}) \\
\mathrm{n}=218 \\
(2003-2012) \\
\text { Age: } 75 \\
(46-89) \text { years. }\end{array}$ & $\begin{array}{c}57.8 \\
(1.6-160.7)\end{array}$ & NR & $\begin{array}{l}\text { 3-Year OS } 68.3 \% \\
\text { (95\% CI=NR) } \\
5 \text {-Year OS } 49.4 \% \\
\text { (95\% CI=NR) }\end{array}$ & $\begin{array}{c}\text { Acute }(\text { NCI-CTC): } \\
0(0) /(0) \\
\text { Late }(\text { RTOG/EORTC): } \\
0(0) / 0(0)\end{array}$ \\
\hline
\end{tabular}


Table III. Continued

\begin{tabular}{|c|c|c|c|c|c|c|c|}
\hline Study & Indication & Method & $\begin{array}{c}\text { FU (range), } \\
\text { months }\end{array}$ & $\begin{array}{c}\text { Additional } \\
\text { treatment }\end{array}$ & Efficacya & $\begin{array}{c}\text { Safety } \\
\text { Radiation morbidity: } \\
\text { grade } 3 / 4, \mathrm{n}(\%)^{\mathrm{b}}\end{array}$ & Conclusion \\
\hline \multicolumn{8}{|c|}{ Bone and soft tissue ( 1 study) } \\
\hline $\begin{array}{l}\text { Sugahara } \\
\text { et al. } \\
2012 \\
(29)\end{array}$ & $\begin{array}{l}\text { Localised } \\
\text { primary } \\
\text { sarcoma } \\
\text { of the } \\
\text { extremities } \\
\text { (medically } \\
\text { inoperable } \\
\text { or declined } \\
\text { surgery) }\end{array}$ & $\begin{array}{c}\text { PCS }(\mathrm{DES}) \\
\mathrm{n}=17 \\
(2000-2010) \\
\text { Age: } 53 \\
\text { (14-87) years. }\end{array}$ & 37 (11-97) & $\begin{array}{c}\text { Variable } \\
\text { (incl. surgery, } \\
\text { chemotherapy) }\end{array}$ & $\begin{array}{c}\text { 3-Year OS: } 68 \% \\
(95 \% \mathrm{CI}=42-86 \%) \\
5-\text { Year OS } 56 \% \\
(95 \% \mathrm{CI}=29-80 \%)\end{array}$ & $\begin{array}{c}\text { Acute (CTCAE): } \\
\text { Skin: } 0(0) / 0(0) \\
\text { Late (CTCAE): } \\
1(1.9) / 0(0)\end{array}$ & $\begin{array}{l}\text { At present } \\
\text { insufficient } \\
\text { scientific } \\
\text { evidence } \\
\text { indicating } \\
\text { superiority/ } \\
\text { inferiority of } \\
\text { CIRT when } \\
\text { compared to } \\
\text { conventional RT } \\
\text { for bone and } \\
\text { soft-tissue } \\
\text { tumours }\end{array}$ \\
\hline
\end{tabular}

CCS: Case-control study; CTCAE: Common Terminology Criteria for Adverse Events; DES: dose-escalation study; EORTC: European Organisation for Research and Treatment of Cancer; FU: follow-up; HRQoL: Health-related Quality of Life; IMRT: intensity-modulated radiation therapy; incl.: including; NSD: not statistically significantly different; NCI-CTC: National Cancer Institute-Common Toxicity Criteria; NR: not reported; NSCLC: non-small cell lung carcinomas; NSD: not statistically significantly different; OS: overall survival; PCS: prospective case series; PRT: proton radiotherapy; RTOG: Radiation Therapy Oncology Group. ${ }^{*}$ Control group of patients treated with PRT: ${ }^{1} \mathrm{n}=57,{ }^{2} \mathrm{n}=43$. Notes: Data based on the original health technology assessment (5). Age and FU in months are median values (range), unless stated otherwise. aSelected results from the systematic review: only overall survival and health-related quality of life are reported outcomes. bOnly selected severe radiation morbidities (grade 3 and grade 4) are reported here. ${ }^{\mathrm{c} C I R T:} 52.6 \mathrm{GyE}$; PRT1: $80 \mathrm{GyE} / 20 \mathrm{Fr}$; PRT2: $60 \mathrm{GyE} / 10 \mathrm{fr} .{ }^{\mathrm{d}}$ Before, during or after radiation therapy. For further details, readers are referred to the original health technology assessment (5).

included in those observational studies and, thus, a potentially significant confounder was not statistically tested. Due to the limitations of heterogeneity and the fact that the primary studies were uncontrolled, those results must be taken with caution and need further primary studies that validate this difference.

Another meta-analysis conducted in 2010 included three studies comparing the effectiveness of different radiotherapy treatment modalities for NSCLC and found statistically significantly higher survival rates associated with CIRT when compared to conventional photon radiotherapy (5-year OS: $42 \%$ vs. 20\%) and no statistically significant difference in survival rates when compared to stereotactic radiotherapy or PRT. The authors, however, noted that the results must be interpreted with caution due to the limited number of patients and limited length of follow-up of the CIRT studies (43).

In conclusion, CIRT can only be called an experimental therapy: more research (prospective controlled and randomised controlled studies) is necessary to reach a sophisticated evidence base for the evaluation of CIRT for cancer therapy.

As always in scientific practice, this systematic review also has weaknesses. The selection of the literature and the RoB assessment was conducted by two independent researchers. The single data extraction method with verification by a second researcher was used in this systematic review. When comparing this method to the double-data extraction method by two independent researchers, the risk of error or of overseeing data may be slightly increased, although this risk is still small in the method used in this study. Furthermore, the selected eligibility criteria, that is, excluding retrospective case series and prospective case series with a high RoB, may have led to not capturing the whole body of available evidence. Moreover, when there was a lack of explicit description of whether a study was prospective or retrospective, the authors took a 'liberal' inclusion strategy and included the respective study.

Another limitation of this report is the pre-defined 54 oncological indications in 12 tumour regions for CIRT. These indications are based on the list of potential indications for CIRT that was provided by the Austrian decision maker that commissioned the HTA. Eight studies were excluded because of wrong indication. Of those, seven focused on CIRT for gynaecological malignancies and one study focused on the use of CIRT for skin cancer. Gynaecological malignancies are, for instance, a good example of another candidate for CIRT (39). Because this systematic review was performed as an HTA, the oncological indications to be used for the evidence synthesis were pre-defined by the Austrian decision maker that commissioned the HTA (5).

The conducted HTA (5) also addressed a broader question, that is, for which tumour types CIRT has been used or is 
Table IV. Summary results of the evidence of efficacy and safety of carbon-ion radiotherapy (CIRT) for prostate and gastrointestinal cancer.

\begin{tabular}{|c|c|c|c|c|c|c|c|}
\hline Study & Indication & Method & $\begin{array}{l}\text { FU (range), } \\
\text { months }\end{array}$ & $\begin{array}{c}\text { Additional } \\
\text { treatment }\end{array}$ & Efficacya & $\begin{array}{c}\text { Safety } \\
\text { Radiation morbidity: } \\
\text { grade } 3 / 4, \mathrm{n}(\%)^{\mathrm{b}}\end{array}$ & Conclusion \\
\hline \multicolumn{8}{|c|}{ Prostate (8 studies) } \\
\hline $\begin{array}{l}\text { Habl } \\
\text { et al. } \\
2016 \\
(11)\end{array}$ & $\begin{array}{c}\text { Localised } \\
\text { prostate cancer }\end{array}$ & $\begin{array}{l}\text { RCT (parallel } \\
\text { assigned, } \\
\text { open-label), } \\
\text { n=92c }(45 \\
\text { CIRT patients) } \\
(2012-2013) * \\
\text { Age: } 68(50-80) \\
\text { years. }\end{array}$ & $\begin{array}{l}22.3 \\
\text { (range: NR) }\end{array}$ & $\begin{array}{c}\text { Variable } \\
(\text { incl. ADT })^{\mathrm{d}}\end{array}$ & $\begin{array}{l}\text { Change in HRQoL } \\
\text { measured with the } \\
\text { QLQ-C30 \& PR25 } \\
\text { scorese : For both } \\
\text { groups, a significant } \\
\text { worsening of QoL was } \\
\text { seen during RT, and several } \\
\text { improvements in QLQC30 } \\
\text { and the QLQPR25 scores } \\
\text { during FU were observed. } \\
\text { During the 6-month FU, } \\
\text { QoL was comparable } \\
\text { between treatment arms, } \\
\text { NSD for most of } \\
\text { QoL scores. }\end{array}$ & $\begin{array}{c}\text { Acute (CTCAE): } \\
\text { Proctitis, CIRT } v s . \\
\text { PRT: } 0(0) / 0(0) v s . \\
2(4.3) / 0(0) \\
\text { Diarrhoea: } 0(0) / 0(0) v s . \\
4(8.7) / 0(0) \\
\text { Cystitis: } 0(0) / 0(0) v s . \\
0(0) / 0(0) \\
\text { Toxicity profiles } \\
\text { between arms: NSD } \\
\text { Late: NR }\end{array}$ & $\begin{array}{c}\text { At present } \\
\text { insufficient } \\
\text { scientific } \\
\text { evidence } \\
\text { indicating } \\
\text { superiority/ } \\
\text { inferiority of } \\
\text { CIRT for prostate } \\
\text { cancer. Direct } \\
\text { comparisons } \\
\text { show n.s. } \\
\text { difference in } \\
\text { acute radiation } \\
\text { morbidity profiles } \\
\text { between CIRT }\end{array}$ \\
\hline $\begin{array}{l}\text { Ishikawa } \\
\text { et al. } \\
2015 \\
(32)\end{array}$ & $\begin{array}{c}\text { Prostate: } \\
\text { T1-T3b }\end{array}$ & $\begin{array}{l}\text { Prospective; } \\
\text { before-after } \\
\text { study, } \mathrm{n}=76 \\
(2010-2011) \\
\text { Age: } 66(53-88) \\
\text { years. }\end{array}$ & $51(8-58)$ & $\begin{array}{c}\text { Variable } \\
\text { (incl. Adjuvant/ } \\
\text { neoadjuvant } \\
\text { ADT) }^{\mathrm{d}}\end{array}$ & $\begin{array}{c}\text { 4-Year OS: } 97.4 \% \\
\text { (95\% CI=93.8-100.0\%) } \\
\text { Change in HRQoL (SF-8): } \\
\text { slight SD long-term } \\
\text { ( }>6 \text { months) physical } \\
\text { component score: } \\
\text { Baseline: } 51.14 \text { ( } \pm 1.85) \\
\text { Short-term (at } 1 \text { months): } \\
51.14 \text { ( } \pm 1.85) \\
\text { Mid-term (at } 3 \text { months): } \\
\text { 50.76 ( } \pm 1.87) \text { (NSD } \\
\text { from baseline) } \\
\text { Long-term (at } 12 \text { months): } \\
\text { PCS: } 47.71 \text { ( } \pm 1.84), \\
\text { SD from baseline } \\
\text { NSD in mental } \\
\text { component summary: } \\
\text { Pre-interventional: } \\
49.18 \text { ( } \pm 1.96) \\
\text { Short-term (at } 1 \text { months): } \\
48.45 \text { ( } \pm 1.96) \\
\text { Mid-term (at } 3 \text { months): } \\
51.63 \text { ( } \pm 1.98) ; \\
\text { Long-term (at } 12 \text { months): } \\
49.75 \text { ( } \pm 1.95) .\end{array}$ & $\begin{array}{l}\text { Acute (NCI-CTC): } \\
\text { GU: } 0(0) / 0(0) \\
\text { GI: } 0(0) / 0(0) \\
\text { Late (NCI-CTC): } \\
\text { GU: } 0(0) / 0(0) \\
\text { GI: } 0(0) / 0(0)\end{array}$ & $\begin{array}{l}\text { and PRT patients } \\
\text { Comparable } \\
\text { HRQoL when } \\
\text { comparing CIRT } \\
\text { to PRT }(6 \mathrm{~m})\end{array}$ \\
\hline $\begin{array}{l}\text { Ishikawa } \\
\text { et al. } \\
2006 \\
(38)\end{array}$ & $\begin{array}{c}\text { Prostate: } \\
\text { T1-T3 }\end{array}$ & $\begin{array}{c}\text { PCS, } n=175 \\
(2000-2003) \\
\text { Age: } 70(53-83) \\
\text { years. }\end{array}$ & $\begin{array}{c}46 \\
\text { (range: NR) }\end{array}$ & $\begin{array}{l}\text { Variable } \\
\text { (incl. Neo- } \\
\text { adjuvant/ } \\
\text { adjuvant } \\
\text { hormonal } \\
\text { therapy; } \\
\text { surgical } \\
\text { castration)d }\end{array}$ & $\begin{array}{c}\text { 4-Year OS 91\% } \\
\text { (95\%CI=87-96\%) } \\
\text { HRQOL: } \\
\text { FACT-G (difference } \\
\text { after } 1 \text {-year): } \\
1.8( \pm 1.1),(p=0.1) \\
\text { ACT-P (difference } \\
\text { after } 1 \text {-year): } \\
2.6( \pm 1.4),(p=0.07)\end{array}$ & $\begin{array}{c}\text { Acute }(\text { RTOG): } \\
\text { GU: } 0(0) / 0(0) \\
\text { GI: } 0(0) / 0(0) \\
\text { Late (RTOG/EORTC): } \\
\text { GU: } 0(0) / 0(0) \\
\text { GI: } 0(0) / 0(0)\end{array}$ & \\
\hline $\begin{array}{l}\text { Niko- } \\
\text { ghosyan } \\
\text { et al. } \\
2011 \\
(35)\end{array}$ & $\begin{array}{l}\text { Intermediate } \\
\text { risk prostate } \\
\text { cancer pts }\end{array}$ & $\begin{array}{c}\text { PCS, } n=14 \\
(1997-2007) \\
\text { Age: } 68(55-75) \\
\text { years. }\end{array}$ & $\begin{array}{l}28 \text { (range: } \\
12-36) \\
\text { ) }\end{array}$ & $\begin{array}{c}\text { Variable } \\
\text { (incl. Adjuvant } \\
\text { hormonal }^{\text {therapy) }}\end{array}$ & $\begin{array}{c}\text { Actuarial, 3-year OS: } \\
100 \%(95 \% \text { CI=NR) }\end{array}$ & $\begin{array}{c}\text { Acute }(\text { CTCAE): } \\
\text { GU: } 0(0) /(0 / 0) \\
\text { GI: } 0(0) / 0(0) \\
\text { Late: NR }\end{array}$ & \\
\hline
\end{tabular}


Table IV. Continued

\begin{tabular}{|c|c|c|c|c|c|c|c|}
\hline Study & Indication & Method & $\begin{array}{c}\text { FU (range), } \\
\text { months }\end{array}$ & $\begin{array}{l}\text { Additional } \\
\text { treatment }\end{array}$ & Efficacya & $\begin{array}{c}\text { Safety } \\
\text { Radiation morbidity: } \\
\text { grade } 3 / 4, \mathrm{n}(\%)^{\mathrm{b}}\end{array}$ & Conclusion \\
\hline $\begin{array}{l}\text { Maruyama } \\
\text { et al. } \\
2017 \\
(33)\end{array}$ & $\begin{array}{l}\text { Intermediate } \\
\text { and high-risk } \\
\text { prostate } \\
\text { cancer }\end{array}$ & $\begin{array}{c}\text { Prospective, } \\
\text { before-after } \\
\text { study, } \mathrm{n}=417 \\
(2000-2007) \\
\text { Age: } 69 \\
(47-92) \text { years. }\end{array}$ & 60 & $\begin{array}{c}\text { Variable } \\
\text { (incl. Adjuvant/ } \\
\text { neoadjuvant } \\
\text { ADT) }\end{array}$ & $\begin{array}{c}\text { HRQoL: } \\
\text { Pre-interventional: } \\
\text { FACT-G: } 84.2( \pm 12.6) \\
\text { FACT-P (baseline): } \\
119.5 \text { ( } \pm 16.9) \\
\text { TOI (baseline): } \\
81.8( \pm 12.0) \\
\text { Post-interventional: NR } \\
\text { Short-term: } \\
\text { FACT-G }(1 \text { month): } \\
83.7( \pm 12.9), \text { NSD } \\
\text { FACT-P }(1 \text { month): } \\
116.2( \pm 17.1), \text { SD. } \\
\text { TOI }(1 \text { month): } \\
77.8( \pm 12.1), \text { SD } \\
\text { Mid-term: NR; } \\
\text { Longer-term: } \\
\text { FACT-G: } \\
\text { At } 12 \text { months: } \\
82.6( \pm 13.7), \text { SD } \\
\text { At } 36 \text { months: } \\
82.4( \pm 14.3), \text { SD } \\
\text { At } 60 \text { months: } \\
82.7( \pm 15.0), \text { SD } \\
\text { FACT-P: } \\
\text { At } 12 \text { months: } \\
116.9( \pm 18.4), \text { SD } \\
\text { At } 36 \text { months: } \\
117.5( \pm 19.3), \text { SD } \\
\text { At } 60 \text { months: } \\
117.6( \pm 20.2), \text { SD } \\
\text { TOI: } \\
12 \text { months: } 80.3( \pm 13.0), \text { NSD } \\
36 \text { months: } 81.6( \pm 13.7), \text { NSD } \\
60 \text { months: } 81.4( \pm 14.6), \text { NSD }\end{array}$ & $\begin{array}{c}\text { Acute: NR } \\
\text { Late (RTOG/EORTC): } \\
\text { GU: } \\
\text { At } 12 \text { months: } 0(0.0) / 0(0.0) \\
\text { At } 36 \text { months: } 0(0.0) / 0(0.0) \\
\text { At } 60 \text { months: } 1(0.3) / 0(0.0)] \\
\text { GI: } \\
\text { At } 12 \text { months: } 0(0.0) / 0(0.0) \\
\text { At } 36 \text { months: } 0(0) / 0(0) \\
\text { At } 60 \text { months: } 0(0.0) / 0(0)\end{array}$ & \\
\hline $\begin{array}{l}\text { Nomiya } \\
\text { et al. } \\
2016 \\
(37)\end{array}$ & $\begin{array}{c}\text { Prostate: } \\
\text { T1-T3b }\end{array}$ & $\begin{array}{c}\text { PCS (multi- } \\
\text { institutional), } \\
\mathrm{n}=2,157 \\
2003-2014)\end{array}$ & $\begin{array}{c}\text { Age: Mean } \\
67(45-92) \\
\text { years. }\end{array}$ & $\begin{array}{c}29 \text { (range: } \\
\text { NR) }\end{array}$ & $\begin{array}{c}\text { Variable } \\
\text { (incl. Adjuvant }^{\text {hormonal therapy) }}\end{array}$ & $\begin{array}{c}\text { 5-Year OS } \\
\text { Low-risk group: } 100 \% \\
\text { (95\%CI=NR); } \\
\text { Intermediate-risk } \\
\text { group: 99\% (95\%CI=NR) } \\
\text { High-risk group: } \\
\text { 96\% (95\%CI=NR) } \\
\text { 10-Year OS: } \\
\text { Low-risk group: } \\
\text { 96\% (95\%CI=NR) } \\
\text { Intermediate-risk } \\
\text { group: } 78 \% \text { (95\% CI=NR) } \\
\text { High-risk group: } 88 \% \\
\text { (95\%CI=NR) }\end{array}$ & $\begin{array}{l}\text { Acute (CTCAE): } \\
\text { GU: } 1(0) / 0(0) \\
\text { GI: } 0(0) / 0(0) \\
\text { Late }(\text { CTCAE): } \\
\text { GU: } 1(0) / 0(0) \\
\text { GI: } 0(0) / 0(0)\end{array}$ \\
\hline $\begin{array}{l}\text { Tsuji } \\
\text { et al. } \\
2005 \\
(36)\end{array}$ & $\begin{array}{l}\text { T1 Prostate } \\
\text { cancer }\end{array}$ & $\begin{array}{c}\text { PCS (DES) } \\
\mathrm{n}=201 \\
(1995-2004) \\
\text { Age: NR }\end{array}$ & NR & $\begin{array}{c}\text { Variable } \\
\text { (incl. Neo- } \\
\text { adjuvant/ } \\
\text { adjuvant } \\
\text { hormonal therapy; } \\
\text { surgery) }\end{array}$ & $\begin{array}{c}5 \text {-Year OS } 89.2 \% \\
(95 \% \mathrm{CI}=\mathrm{NR})\end{array}$ & $\begin{array}{c}\text { Acute: NR } \\
\text { Late (RTOG/EORTC): } \\
\text { Bladder/urethra: } 0(0) / 0(0) \\
\text { Rectum: } 0(0) / 0(0)\end{array}$ & \\
\hline
\end{tabular}


Table IV. Continued

\begin{tabular}{|c|c|c|c|c|c|c|c|}
\hline Study & Indication & Method & $\begin{array}{l}\text { FU (range) } \\
\text { months }\end{array}$ & $\begin{array}{c}\text { Additional } \\
\text { treatment }\end{array}$ & Efficacya & $\begin{array}{c}\text { Safety } \\
\text { Radiation morbidity: } \\
\text { grade } 3 / 4, \mathrm{n}(\%)^{\mathrm{b}}\end{array}$ & Conclusion \\
\hline $\begin{array}{l}\text { Wakatsuki } \\
\text { et al. } \\
2008 \\
(34)\end{array}$ & $\begin{array}{c}\text { T1-T3 } \\
\text { Prostate } \\
\text { cancer }\end{array}$ & $\begin{array}{c}\text { Prospective } \\
\text { before-after- } \\
\text { study, } n=194 \\
(2000-2004) \\
\text { Age: } 69 \\
(53-83) \text { years. }\end{array}$ & NR & $\begin{array}{l}\text { Variable } \\
\text { (incl. Neo- } \\
\text { adjuvant/ } \\
\text { adjuvant } \\
\text { hormonal } \\
\text { therapy; } \\
\text { surgery) }^{\text {d }}\end{array}$ & $\begin{array}{c}\text { HRQoLf: } \\
\text { patients receiving CIRT } \\
\text { alone (n=25): no } \\
\text { significant differences } \\
\text { in FACT-G and } \\
\text { FACT-P results when } \\
\text { comparing baseline } \\
\text { scores to the scores } \\
\text { post interventional and } \\
\text { at } 12 \text { months after CIRT: } \\
\text { Baseline: } \\
\text { FACT-G: } 88.4( \pm 13.2) \\
\text { FACT-P: } 122.6( \pm 19.8) ; \\
\text { postinterventional: } \\
\text { FACT-G: } 89.2( \pm 11.3), \text { NSD } \\
\text { FACT-P: } 122.4( \pm 16.6), \text { NSD } \\
\text { Short-term: NR; } \\
\text { Mid-term: NR; } \\
\text { Longer-term }(\text { at } 12 \text { months): } \\
\text { FACT-G: } 89.1( \pm 13.6), \text { NSD } \\
\text { FACT-P: } 123.8( \pm 20.3), \text { NSD } \\
\text { Patients receiving CIRT+ } \\
\text { ADT (n=125): lower FACT-G } \\
\text { and FACT-P scores at } 12 \text { months } \\
\text { compared to baseline, SD. } \\
\text { Baseline: } \\
\text { FACT-G: } 86.1( \pm 19.4), \text { NSD } \\
\text { FACT-P: } 120.0( \pm 26.1), \text { NSD } \\
\text { Postinterventional: } \\
\text { FACT-G: } 85.5( \pm 21.2), \text { NSD } \\
\text { FACT-P: } 118.0( \pm 28.4), \text { NSD } \\
\text { Short-term: NR } \\
\text { Mid-term: NR; } \\
\text { Longer-term }(12 \text { months): } \\
\text { FACT-G: } 83.9( \pm 21.7), \text { SD } \\
\text { FACT-P: } 116.7( \pm 29.1), \text { SD }\end{array}$ & NR & \\
\hline \multicolumn{8}{|c|}{ Gastrointestinal (2 studies) } \\
\hline $\begin{array}{l}\text { Akutsu } \\
\text { et al. } \\
2012 \\
(30)\end{array}$ & $\begin{array}{c}\text { T1-T3 } \\
\text { Thoracic } \\
\text { ESCC: T1 } \\
(\mathrm{n}=12)+\mathrm{T} 2 \\
(\mathrm{n}=8)+\mathrm{T} 3 \\
(\mathrm{n}=11)\end{array}$ & $\begin{array}{c}\text { PCS }(\text { DES }), \\
n=31 \\
(2004-2008) \\
\text { Age: Mean } \\
65.4 \pm 7.1 \text { years. }\end{array}$ & NR & $\begin{array}{l}\text { Variable } \\
\text { (incl. } \\
\text { Surgery) }\end{array}$ & $\begin{array}{c}\text { 1-year OS } \\
\text { Stage 1: } 91 \% \\
\text { (95\%CI=NR), stage 2: } 100 \% \\
\text { (95\% CI=NR), stage 3: } \\
71 \% \text { (95\%CI=NR) } \\
\text { 3-year OS } \\
\text { stage 1: } 81 \%(95 \% \mathrm{CI}=\mathrm{NR}), \\
\text { stage 2: } 85 \%(95 \% \mathrm{CI}=\mathrm{NR}), \\
\text { stage 3: } 43 \%(95 \% \mathrm{CI}=\mathrm{NR}) \\
\text { 5-year OS } \\
\text { stage 1: } 61 \%(95 \% \mathrm{CI}=\mathrm{NR}) \\
\text { stage 2: } 77 \%(95 \% \mathrm{CI}=\mathrm{NR}) \\
\text { stage 3: } 29 \%(95 \% \mathrm{CI}=\mathrm{NR})\end{array}$ & $\begin{array}{c}\text { Acute (CTCAE): } \\
\text { Oesophagus: } 0(0) / 0(0) \\
\text { Skin: } 0(0) / 0(0) \\
\text { Respiratory: } 1(3.2) / 0(0) \\
\text { Blood: } 0(0) / 0(0) \\
\text { Late: "No toxicities } \\
\text { including operative } \\
\text { complications were } \\
\text { observed after the } 91 \text { st } \\
\text { day from the first } \\
\text { treatment" (data not } \\
\text { reported in the study). }\end{array}$ & $\begin{array}{c}\text { At present } \\
\text { insufficient } \\
\text { scientific } \\
\text { evidence } \\
\text { indicating } \\
\text { superiority/ } \\
\text { inferiority of } \\
\text { CIRT for gastro- } \\
\text { intestinal } \\
\text { tumours }\end{array}$ \\
\hline $\begin{array}{l}\text { Yamada } \\
\text { et al. } \\
2016 \\
(31)\end{array}$ & $\begin{array}{c}\text { Rectal cancer } \\
\text { without } \\
\text { distant } \\
\text { metastasis }\end{array}$ & $\begin{array}{c}\text { PCS }(\mathrm{DES}) \\
\mathrm{n}=184 \\
(2001-2012) \\
\text { Age: } 61.3 \\
(37-79) \text { years. }\end{array}$ & $42(7-131)$ & $\begin{array}{c}\text { Variable } \\
\text { (incl. Primary } \\
\text { tumour OP) }^{\mathrm{d}}\end{array}$ & $\begin{array}{c}\text { 3-Year OS: } 72 \% \\
\text { (95\% I }=66 \%-79) \\
\text { 5-Year OS: } 53 \% \\
(95 \% \mathrm{CI}=45 \%-62 \%)\end{array}$ & $\begin{array}{c}\text { Acute (CTCAE): } \\
\text { dose-escalation }(\mathrm{n}=37) \text { : } \\
\text { Skin: } 0(0) / 0(0) \\
\text { GI tract: } 0(0) / 0(0) \\
\text { Urinary: } 0(0) / 0(0)\end{array}$ & \\
\hline
\end{tabular}


Table IV. Continued

\begin{tabular}{cccc}
\hline Study Indication & Method $\begin{array}{c}\mathrm{FU} \text { (range), } \\
\text { months }\end{array}$ & $\begin{array}{c}\text { Additional } \\
\text { treatment }\end{array}$ & $\begin{array}{c}\text { Safety } \\
\text { Radiation morbidity: } \\
\text { grade } 3 / 4, \mathrm{n}(\%)^{\mathrm{b}}\end{array}$ \\
\hline & $\begin{array}{c}\text { Efficacya } \\
\text { Phase } 2 \text { study }(\mathrm{n}=143): \\
\text { Skin: } 0(0) / 0(0) \\
\text { GI: } 0(0) / 0(0)\end{array}$ \\
Urinary: $0(0) / 0(0)$ \\
Late (RTOG/EORTC: \\
Dose-escalation $(\mathrm{n}=37):$ \\
Skin: $0(0) / 0(0)$ \\
GI tract: $0(0) / 0(0)$ \\
Urinary: $0(0) / 0(0)$ \\
Phase $2(\mathrm{n}=143):$ \\
Skin: $2(1.4) / 0(0)$ \\
GI tract: $1(0.6) / 0(0)$ \\
Urinary: $0(0) / 0(0)$
\end{tabular}

ADT: Androgen deprivation therapy; CI: confidence interval; CIRT: carbon-ion radiotherapy; CTCAE: Common Terminology Criteria for Adverse Events; DES: Dose Escalation Study; EORTC: European Organisation for Research and Treatment of Cancer; ESCC: esophageal squamous cell carcinoma; FACT-G: Functional Assessment of Cancer Therapy - General; FACT-P: Functional Assessment of Cancer Therapy - Prostate; FU: follow-up; GI: gastrointestinal; GU: genitourinary; HRQoL: Health-related Quality of Life; incl.: including; NCI-CTC: National Cancer Institute-Common Toxicity Criteria; NR: not reported; NSD: not statistically significantly different; OP: operation; OS: overall survival; PCS: prospective case series; PRT: Proton radiotherapy; QLQ-C30: quality of life of cancer patients; QLQ-PR25: quality of life of prostate cancer; RTOG: Radiation Therapy Oncology Group; SF-8: short-form health survey; TOI: Trial Outcome Index. *Control group of 46 patients treated with PRT. Notes: Data based on the original health technology assessment (5). In single-arm studies, the difference refers to the difference from the baseline score. Age and FU in months are median values

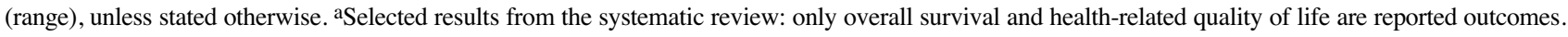
bonly selected severe radiation morbidities (grade 3 and grade 4) are reported here. ${ }^{c} 92$ patients were enrolled in the clinical study (11) but 1 patient dropped out. ${ }^{\mathrm{d} B e f o r e}$, during or after radiation therapy. ${ }^{\mathrm{e}}$ Differences in HRQoL between treatment arms were only found for some subscales: urinary and bowel symptoms scores were statistically significantly different between treatment arms but data and $p$-values for head-to head comparison were insufficiently described. fUniversity of California-Los Angeles Prostate Cancer Index (UCLA-PCI) scores were measured for some patients: NSD between scores at baseline, post-intervention and 12 months (34). In addition, more nuanced data on quality of life and the respective sub-score results can be found in the primary study (34). For further details, readers are referred to the original health technology assessment (5).

currently used. For this research question, no filter was used, e.g. regarding oncological indications, publication period or RoB. After having assessed the RoB, stricter inclusion criteria were applied. The results of the broad research question of the HTA are not part of this report.

When looking at innovative new cancer treatments, ethical reasons sometimes hinder reaching a sophisticated evidence base in fields where a therapy has strongly proven benefits and in which it is not feasible to consolidate those benefits through empirical experimental research using RCTs. In a report by the Belgian Health Care Knowledge Center on the effectiveness and safety of PRT for paediatric cancer types, no RCT was found and a potential reluctance to randomise patients to PRT was discussed (44). It is pointed out that it is difficult to understand why it would be unethical to perform RCTs in the context of PRT except for some tumour types. A recent report by the same institution evaluating the evidence of PRT in adults (45) even discussed that one may consider treatment of patients with PRT without conducting RCTs to be unethical due to the fact that benefits would be based on assumptions solely. However, the discussion regarding the necessity of conducting/not conducting high-quality research through RCTs should be much clearer in the context of CIRT, since the medical literature describes CIRT as a two-edged sword with unique advantages, but also potential harms, that is, risks to severe injury to critical organs (2). Therefore, and to the best of our knowledge, ethical reasons legitimating not undertaking RCTs may not be adequate, especially because numerous other novel cancer treatments also co-exist alongside CIRT (e.g. CyberKnife ${ }^{\circledR}$, and stereotactic radiation therapy).

Suffice to say that results from RCTs are urgently needed to prove the superiority or inferiority of CIRT when compared to conventional radiotherapy. Currently, it is not yet clear for which tumour types the theoretical benefits of CIRT translate into clinical benefits.

Furthermore, the cost dimension must also be taken into consideration when it comes to CIRT. Besides the need for health economic evaluations of CIRT (incl. acquisition costs), questions related to the sustainability of those cancer therapy 
centres are to be raised. One Hadron therapy centre in Germany, for instance, declared bankruptcy recently (46). This leads to further questions regarding resource allocation and the structural dimension of such Hadron therapy centres that need to be debated to reach a sustainable way of dealing with innovative and costly cancer therapies with high uncertainty regarding its comparative effectiveness and safety. The aim must hereby be to reach the greatest patient-relevant outcomes (PROs) for patients with cancer and further research - including, inter alia, primary research (ideally RCTs), but also health economic evaluations and health service research evaluations - can provide a scientific basis to make decisions that help reach this aim efficiently and sustainably.

\section{Conflicts of Interest}

The Authors declare no conflicts of interest exist in regard to this study.

\section{Authors' Contributions}

Gregor Goetz: Primary author (major contributions to all aspects of conducting the systematic review). Marija Mitic: Medical consultant (advice in structuring the list of oncological indications/body regions), second author for the study selection, quality appraisal, data-extraction and evidence synthesis. Tarquin Mittermayr: Conduction of the systematic literature search. Claudia Wild: Critical revision of the work for important intellectual content, supervision of conducting the systematic review. All Authors approved the final version to be published, and agree with its content (questions related to the accuracy or integrity of any part of the work were appropriately investigated and resolved).

\section{References}

1 Fukumura A, Tsujii H, Kamada T, Baba M, Tsuji H, Kato H, Kato S, Yamada S, Yasuda S, Yanagi T, Kato H, Hara R, Yamamoto N, Mizoe J, Akahane K, Fukuda S, Furusawa Y, Iwata Y, Kanai T, Kanematsu N, Kitagawa A, Matsufuji N, Minohara S, Miyahara N, Mizuno H, Murakami T, Nishizawa K, Noda K, Takada E and Yonai S: Carbon-ion radiotherapy: Clinical aspects and related dosimetry. Radiat Prot Dosimetry 137(1-2): 149-155, 2009. PMID: 19812127 . DOI: $10.1093 / \mathrm{rpd} / \mathrm{ncp} 188$

2 Tsuji H, T. K, Shirai T, Noda K, Tsuji H and Karasawa K: Carbon-ion radiotherapy. Principles, practices, and treatment planning. Springer Japan, 2014.

3 Particle Therapy Co-Operative Group (PTCOGC): Particle therapy facilities in operation (last update: Dec 2017), 2017. Available at https://www.ptcog.ch/index.php/facilities-inoperation. Last accessed on 05.10.2017.

4 Particle Therapy Co-Operative Group (PTCOGC): Particle therapy patient statistics (per end of 2016). Available at https:// www.ptcog.ch/archive/patient_statistics/PatientstatisticsupdateDec2016.pdf. Last accessed on 05.10.2017.

5 Goetz G and Mitic M: Carbon-ion beam radiotherapy (CIRT) for cancer treatment: A systematic review of effectiveness and safety for 12 oncologic indications. Vienna, Ludwig Boltzmann Institute for Health Technology Assessment, 2018. Available at http://eprints.hta.lbg.ac.at/1174/1/HTA-Projektbericht_Nr.101.pdf. Last accessed on 10.01.2019.

6 European Network for Health Technology Assessment (EUnetHTA): HTA core model for rapid relative effectiveness, 2015. Available at https://www.eunethta.eu/wp-content/ uploads/2018/06/HTACoreModel_ForRapidREAs4.2-3.pdf. Last accessed on 15.10.2018.

7 Moher D, Liberati A, Tetzlaff J, Altman DG and Group P: Preferred reporting items for systematic reviews and metaanalyses: The prisma statement. Int J Surg 8(5): 336-341, 2010. PMID: 20171303. DOI: 10.1016/j.ijsu.2010.02.007

8 Moga C, Guo B, Schopflocher D and Harstall C: Development of a quality appraisal tool for case series studies using a modified Delphi technique, 2012. Available at https://www.ihe.ca/ download/development_of_a_quality_appraisal_tool_for_case_se ries_studies_using_a_modified_delphi_technique.pdf. Last accessed on 27.09.2017.

9 EUnetHTA Joint Action 2 WP: Levels of evidence: Internal validity (of randomized controlled trials), 2013. Available at http://www.eunethta.eu/sites/5026.fedimbo.belgium.be/files/Intern al_Validity.pdf. Last accessed on 10.10.2017.

10 EUnetHTA Joint Action 2 WP: Internal validity of nonrandomised studies (nrs) on interventions, 2015. Available at http://www.eunethta.eu/sites/5026.fedimbo.belgium.be/files/201507-06_Non-RCT_Assessment_WP7_SG3_Guideline_final.pdf. Last accessed on 10.10.2017.

11 Habl G, Uhl M, Katayama S, Kessel KA, Hatiboglu G, Hadaschik B, Edler L, Tichy D, Ellerbrock M, Haberer T, Wolf MB, Schlemmer HP, Debus J and Herfarth K: Acute toxicity and quality of life in patients with prostate cancer treated with protons or carbon-ions in a prospective randomized phase II study-the IPI trial. Int J Radiat Oncol Biol Phys 95(1): 435-443, 2016. PMID: 27084659. DOI: 10.1016/j.ijrobp.2016.02.025

12 Higgins JP, Altman DG, Gotzsche PC, Juni P, Moher D, Oxman AD, Savovic J, Schulz KF, Weeks L, Sterne JA, Cochrane Bias Methods Group and Cochrane Statistical Methods Group: The Cochrane Collaboration's tool for assessing risk of bias in randomised trials. BMJ 343: d5928, 2011. PMID: 22008217. DOI: $10.1136 / \mathrm{bmj} . \mathrm{d} 5928$

13 Mizoe JE, Hasegawa A, Takagi R, Bessho H, Onda T and Tsujii $\mathrm{H}$ : Carbon-ion radiotherapy for skull base chordoma. Skull Base 19(3): 219-224, 2009. PMID: 19881902. DOI: 10.1055/s-00281114295

14 Schulz-Ertner D, Nikoghosyan A, Hof H, Didinger B, Combs SE, Jakel O, Karger CP, Edler L and Debus J: Carbon-ion radiotherapy of skull base chondrosarcomas. Int J Radiat Oncol Biol Phys 67(1): 171-177, 2007. PMID: 17056193. DOI: 10.1016/j.jirobp.2006.08.027

15 Uhl M, Welzel T, Oelmann J, Habl G, Hauswald H, Jensen A, Ellerbrock M, Debus J and Herfarth K: Active raster scanning with carbon-ions: Reirradiation in patients with recurrent skull base chordomas and chondrosarcomas. Strahlenther Onkol 190(7): 686-691, 2014. PMID: 24663287. DOI: 10.1007/s00066014-0608-2

16 Mizoe JE, Tsujii H, Hasegawa A, Yanagi T, Takagi R, Kamada T, Tsuji H, Takakura K and Organizing Committee of the Central Nervous System Tumor Working Group: Phase I/II clinical trial of carbon-ion radiotherapy for malignant gliomas: Combined 
$\mathrm{x}$-ray radiotherapy, chemotherapy, and carbon-ion radiotherapy. Int J Radiat Oncol Biol Phys 69(2): 390-396, 2007. PMID: 17459607. DOI: $10.1016 /$ j.jirobp.2007.03.003

17 Hasegawa A, Mizoe JE, Tsujii H, Kamada T, Jingu K, Iwadate Y, Nakazato $Y$, Matsutani $M$, Takakura $K$ and Organizing Committee of the Central Nervous System Tumor Working Group: Experience with carbon-ion radiotherapy for WHO grade 2 diffuse astrocytomas. Int J Radiat Oncol Biol Phys 83(1): 100106, 2012. PMID: 22104357. DOI: 10.1016/j.ijrobp.2011.06.1952

18 Shirai K, Saitoh JI, Musha A, Abe T, Kobayashi D, Takahashi T, Tamaki T, Kawamura H, Takayasu Y, Shino M, Toyoda M, Takahashi K, Hirato J, Yokoo S, Chikamatsu K, Ohno T, Nakano $\mathrm{T}$ and Working Group on Head and Neck Tumours: Prospective observational study of carbon-ion radiotherapy for non-squamous cell carcinoma of the head and neck. Cancer Sci 108(10): 20392044, 2017. PMID: 28730646. DOI: 10.1111/cas.13325

19 Mizoe JE, Hasegawa A, Jingu K, Takagi R, Bessyo H, Morikawa T, Tonoki M, Tsuji H, Kamada T, Tsujii H, Okamoto Y and Organizing Committee for the Working Group for Head-andNeck Cancer: Results of carbon-ion radiotherapy for head and neck cancer. Radiother Oncol 103(1): 32-37, 2012. PMID: 22321201. DOI: 10.1016/j.radonc.2011.12.013

20 Jensen AD, Nikoghosyan AV, Lossner K, Haberer T, Jakel O, Munter MW and Debus J: Cosmic: A regimen of intensitymodulated radiation therapy plus dose-escalated, raster-scanned carbon-ion boost for malignant salivary gland tumors: Results of the prospective phase 2 trial. Int J Radiat Oncol Biol Phys 93(1): 37-46, 2015. PMID: 26279022. DOI: 10.1016/j.jirobp. 2015.05.013

21 Jingu K, Tsujii H, Mizoe JE, Hasegawa A, Bessho H, Takagi R, Morikawa T, Tonogi M, Tsuji H, Kamada T, Yamada S and Organizing Committee for the Working Group for Head-and-Neck Cancer: Carbon-ion radiation therapy improves the prognosis of unresectable adult bone and soft-tissue sarcoma of the head and neck. Int J Radiat Oncol Biol Phys 82(5): 2125-2131, 2012. PMID: 21745719. DOI: 10.1016/j.ijrobp.2010.08.043

22 Schulz-Ertner D, Nikoghosyan A, Didinger B, Munter M, Jakel O, Karger CP and Debus J: Therapy strategies for locally advanced adenoid cystic carcinomas using modern radiation therapy techniques. Cancer 104(2): 338-344, 2005. PMID: 15937907. DOI: $10.1002 /$ cncr.21158

23 Yamamoto N, Miyamoto T, Nakajima M, Karube M, Hayashi K, Tsuji H, Tsujii H, Kamada T and Fujisawa T: A dose escalation clinical trial of single-fraction carbon-ion radiotherapy for peripheral stage I non-small cell lung cancer. J Thorac Oncol 12(4): 673-680, 2017. PMID: 28007628. DOI: 10.1016/ j.jtho.2016.12.012

24 Takahashi W, Nakajima M, Yamamoto N, Yamashita H, Nakagawa K, Miyamoto T, Tsuji H, Kamada T and Fujisawa T: A prospective nonrandomized phase I/II study of carbon-ion radiotherapy in a favorable subset of locally advanced non-small cell lung cancer (NSCLC). Cancer 121(8): 1321-1327, 2015. PMID: 25641119. DOI: 10.1002/cncr.29195

25 Iwata H, Demizu Y, Fujii O, Terashima K, Mima M, Niwa Y, Hashimoto N, Akagi T, Sasaki R, Hishikawa Y, Abe M, Shibamoto Y, Murakami M and Fuwa N: Long-term outcome of proton therapy and carbon-ion therapy for large (T2A-T2BNOM0) non-small-cell lung cancer. J Thorac Oncol 8(6): 726-735, 2013. PMID: 23459403. DOI: 10.1097/JTO.0b013e318288ab02

26 Iwata H, Murakami M, Demizu Y, Miyawaki D, Terashima K, Niwa Y, Mima M, Akagi T, Hishikawa Y and Shibamoto Y: High- dose proton therapy and carbon-ion therapy for stage I nonsmall cell lung cancer. Cancer 116(10): 2476-2485, 2010. PMID: 20225229. DOI: $10.1002 /$ cncr.24998

27 Miyamoto T, Baba M, Yamamoto N, Koto M, Sugawara T, Yashiro T, Kadono K, Ezawa H, Tsujii H, Mizoe JE, Yoshikawa K, Kandatsu S, Fujisawa T and Working Group for Lung Cancer: Curative treatment of stage I non-small-cell lung cancer with carbon-ion beams using a hypofractionated regimen. Int J Radiat Oncol Biol Phys 67(3): 750-758, 2007. PMID: 17293232. DOI: 10.1016/j.ijrobp.2006.10.006

28 Miyamoto T, Baba M, Sugane T, Nakajima M, Yashiro T, Kagei K, Hirasawa N, Sugawara T, Yamamoto N, Koto M, Ezawa H, Kadono K, Tsujii H, Mizoe JE, Yoshikawa K, Kandatsu S, Fujisawa $\mathrm{T}$ and Working Group for Lung Cancer: Carbon-ion radiotherapy for stage I non-small cell lung cancer using a regimen of four fractions during 1 week. J Thorac Oncol 2(10): 916-926, 2007. PMID: 17909354. DOI: 10.1097/JTO.0b01 3e3181560a68

29 Sugahara S, Kamada T, Imai R, Tsuji H, Kameda N, Okada T, Tsujii H, Tatezaki S, Working Group for Bone and Soft-tissue Sarcomas: Carbon-ion radiotherapy for localized primary sarcoma of the extremities: Results of a phase I/II trial. Radiother Oncol 105(2): 226-231, 2012. PMID: 23068710. DOI: 10.1016/ j.radonc .2012 .09 .010

30 Akutsu Y, Yasuda S, Nagata M, Izumi Y, Okazumi S, Shimada H, Nakatani Y, Tsujii H, Kamada T, Yamada S and Matsubara H: A phase I/II clinical trial of preoperative short-course carbon-ion radiotherapy for patients with squamous cell carcinoma of the esophagus. J Surg Oncol 105(8): 750-755, 2012. PMID: 22012645. DOI: $10.1002 /$ jso.22127

31 Yamada S, Kamada T, Ebner DK, Shinoto M, Terashima K, Isozaki Y, Yasuda S, Makishima H, Tsuji H, Tsujii H, Isozaki T, Endo S, Takahashi K, Sekimoto M, Saito N, Matsubara H and Working Group on Locally Recurrent Rectal Cancer: Carbon-ion radiation therapy for pelvic recurrence of rectal cancer. Int $\mathbf{J}$ Radiat Oncol Biol Phys 96(1): 93-101, 2016. PMID: 27375166. DOI: 10.1016/j.ijrobp.2016.04.022

32 Ishikawa H, Katoh H, Kaminuma T, Kawamura H, Ito K, Matsui H, Hirato J, Shimizu N, Takezawa Y, Tsuji H, Suzuki K, Ohno T, Nakano T and Group for Genitourinary Tumors at Gunma Heavy Ion Medical Centre: Carbon-ion radiotherapy for prostate cancer: Analysis of morbidities and change in health-related quality of life. Anticancer Res 35(10): 5559-5566, 2015. PMID: 26408726.

33 Maruyama K, Tsuji H, Nomiya T, Katoh H, Ishikawa H, Kamada T, Wakatsuki M, Akakura K, Shimazaki J, Aoyama H, Tsujii H and Working Group for Genitourinary Tumours: Five-year quality of life assessment after carbon-ion radiotherapy for prostate cancer. J Radiat Res 58(2): 260-266, 2017. PMID: 28043947. DOI: $10.1093 / \mathrm{jrr} / \mathrm{rrw} 122$

34 Wakatsuki M, Tsuji H, Ishikawa H, Yanagi T, Kamada T, Nakano T, Suzuki H, Akakura K, Shimazaki J and Tsujii H: Quality of life in men treated with carbon-ion therapy for prostate cancer. Int J Radiat Oncol Biol Phys 72(4): 1010-1015, 2008. PMID: 18495370. DOI: 10.1016/j.ijrobp.2008.02.035

35 Nikoghosyan AV, Schulz-Ertner D, Herfarth K, Didinger B, Munter MW, Jensen AD, Jakel O, Hoess A, Haberer T and Debus $\mathrm{J}$ : Acute toxicity of combined photon IMRT and carbon-ion boost for intermediate-risk prostate cancer - acute toxicity of $12 \mathrm{C}$ for PC. Acta Oncol 50(6): 784-790, 2011. PMID: 21767175. DOI: 10.3109/0284186X.2011.584558 
36 Tsuji H, Yanagi T, Ishikawa H, Kamada T, Mizoe JE, Kanai T, Morita S, Tsujii $\mathrm{H}$ and Working Group for Genitourinary Tumours: Hypofractionated radiotherapy with carbon-ion beams for prostate cancer. Int J Radiat Oncol Biol Phys 63(4): 11531160, 2005. PMID: 15990247. DOI: 10.1016/j.ijrobp.2005.04.022

37 Nomiya T, Tsuji H, Kawamura H, Ohno T, Toyama S, Shioyama Y, Nakayama Y, Nemoto K, Tsujii H and Kamada T: A multiinstitutional analysis of prospective studies of carbon-ion radiotherapy for prostate cancer: A report from the Japan Carbonion Radiation Oncology Study Group (J-CROS). Radiother Oncol 121(2): 288-293, 2016. PMID: 27836119. DOI: 10.1016/ j.radonc.2016.10.009

38 Ishikawa H, Tsuji H, Kamada T, Yanagi T, Mizoe JE, Kanai T, Morita S, Wakatsuki M, Shimazaki J, Tsujii H and Working Group for Genitourinary Tumours: Carbon-ion radiation therapy for prostate cancer: Results of a prospective phase II study. Radiother Oncol 81(1): 57-64, 2006. PMID: 16971008. DOI: 10.1016/j.radonc.2006.08.015

39 Mohamad O, Yamada S and Durante M: Clinical indications for carbon-ion radiotherapy. Clin Oncol (R Coll Radiol) 30(5): $317-$ 329, 2018. PMID: 29402598. DOI: 10.1016/j.clon.2018.01.006

40 Igaki H, Mizumoto M, Okumura T, Hasegawa K, Kokudo N and Sakurai H: A systematic review of publications on charged particle therapy for hepatocellular carcinoma. Int J Clin Oncol 23(3): 423-433, 2018. PMID: 28871342. DOI: 10.1007/s10147017-1190-2

41 Combs SE and Debus J: Treatment with heavy charged particles: Systematic review of clinical data and current clinical (comparative) trials. Acta Oncol 52(7): 1272-1286, 2013. PMID: 23964656. DOI: $10.3109 / 0284186$ X.2013.818254

42 Ramaekers BL, Pijls-Johannesma M, Joore MA, van den Ende P, Langendijk JA, Lambin P, Kessels AG and Grutters JP: Systematic review and meta-analysis of radiotherapy in various head and neck cancers: Comparing photons, carbon-ions and protons. Cancer Treat Rev 37(3): 185-201, 2011. PMID: 20817407. DOI: $10.1016 /$ j.ctrv.2010.08.004
43 Grutters JP, Kessels AG, Pijls-Johannesma M, De Ruysscher D, Joore MA and Lambin P: Comparison of the effectiveness of radiotherapy with photons, protons and carbon-ions for non-small cell lung cancer: A meta-analysis. Radiother Oncol 95(1): 32-40, 2010. PMID: 19733410. DOI: 10.1016/j.radonc.2009.08.003

44 Leroy R, Benahmed N, Hulstaert F, Mambourg F, Fairon N, Van Eycken LR, Benahmed N, Hulstaert F, Mambourg F, Fairon N and Van Eycken L: Hadron therapy in children - an update of the scientific evidence for 15 paediatric cancers. Brussels, Belgian Health Care Knowledge Centre (KCE), 2015. Available at https://kce.fgov.be/sites/default/files/atoms/files/KCE_235_Hadro n\%20Therapy_Report.pdf. Last accessed on 15.09.2017.

45 Vlayen J, García Fernández LI, Boterberg T and San Miguel L: Proton beam therapy in adults - a systematic review. Brussels, Belgian Health Care Knowledge Centre (KCE), 2019. Available at https://kce.fgov.be/sites/default/files/atoms/files/KCE_307_ Proton_beam_therapy_adults_Report_1.pdf. Last accessed on 08.02.2019.

46 Aerzteblatt: Insolvenzantrag für marburger ionenstrahl-therapiezentrum gestellt. 2018. Available at https://www.aerzteblatt.de/ nachrichten/97890/Insolvenzantrag-fuer-Marburger-IonenstrahlTherapiezentrum-gestellt. Last accessed on 15.09.2018.
Received February 3, 2019

Revised March 12, 2019

Accepted March 14, 2019 